\title{
CFD Simulation of the Discharge Flow from Standard Rushton Impeller
}

\author{
Bohuš Kysela, ${ }^{1}$ Jiř́i Konfrǒtt, ${ }^{1}$ Ivan Fořt, ${ }^{2}$ and Zdeněk Chára ${ }^{1}$ \\ ${ }^{1}$ Institute of Hydrodynamics AS CR, v. v. i., Pod Patankou 30/5, 16612 Prague, Czech Republic \\ ${ }^{2}$ Department of Process Engineering, Faculty of Mechanical Engineering, Czech Technical University in Prague, \\ Technicka 4, 16607 Prague, Czech Republic
}

Correspondence should be addressed to Bohuš Kysela; kysela@ih.cas.cz

Received 5 August 2013; Revised 22 November 2013; Accepted 23 November 2013; Published 29 January 2014

Academic Editor: Alírio Rodrigues

Copyright (C) 2014 Bohuš Kysela et al. This is an open access article distributed under the Creative Commons Attribution License, which permits unrestricted use, distribution, and reproduction in any medium, provided the original work is properly cited.

\begin{abstract}
The radial discharge jet from the standard Rushton turbine was investigated by the CFD calculations and compared with results from the Laser Doppler Anemometry (LDA) measurements. The Large Eddy Simulation (LES) approach was employed with Sliding Mesh (SM) model of the impeller motion. The obtained velocity profiles of the mean ensemble-averaged velocity and r.m.s. values of the fluctuating velocity were compared in several distances from the impeller blades. The calculated values of mean ensembleaveraged velocities are rather in good agreement with the measured ones as well as the derived power number from calculations. However, the values of fluctuating velocities are obviously lower from LES calculations than from LDA measurements.
\end{abstract}

\section{Introduction}

The flow inside the agitated vessel has a key role in the mixing processes. Only the CFD modeling gives us the complex information about the whole flow field in contrast with the results of the experimental measurements. The enormous progress of the computational equipment has allowed using more exacting turbulence models for solution of the flow in the agitated vessel. Nowadays not only Reynolds Averaged Navier-Stokes (RANS) models (for example, $k-\varepsilon$ [1-7], $k-\omega$, and Reynolds Stress Model [4, 5]) are commonly used, but also other more sophisticated methods become topical (for example, Detached Eddy Simulation [8], Large Eddy Simulation [8-15] and even Direct Numerical Simulation [15]). However, all calculations also need some validation by the experimental results or by the analytical models. The radial impellers are most often used in experiments and calculations [16-21], namely, Rushton turbine, and there are also analytical models, where the impeller discharge stream is modeled as a turbulent jet $[1,2,16,19,20]$.

The aim of this study is the description of the turbulent velocity field in the discharge stream from the standard Rushton turbine impeller in the pilot plant mixing vessel with baffles at the wall. Investigation will be carried out experimentally (LDA technique) as well as by means of CFD simulation, where the LES approach was used with Sliding Mesh model for the impeller movement because Sliding Mesh approach has a potential to be used as a design tool to screen different configurations, but it has not been sufficiently validated for turbulent regime [4].

\section{CFD Calculations}

A commercial ANSYS FLUENT v.13.0 solver of the finite volume method was employed. The turbulence was modelled by Large Eddy Simulation (LES) with Sliding Mesh (SM) simulation for the impeller movement. The solver was pressure based and for pressure-velocity coupling the PISO method was used. The Smagorinsky-Lilly model was used as the subgrid-scale model with second-order implicit scheme. The schemes for spatial discretization were GradientLeast Squares Cell based, Pressure-Second Order, and Momentum-Second Order Upwind. The boundary conditions were set: water level to the symmetry and others to the no slip wall, where the part of the impeller shaft outside of the sliding region is defined as wall with impeller speed velocity. The walls of the vessel and baffles are provided by 


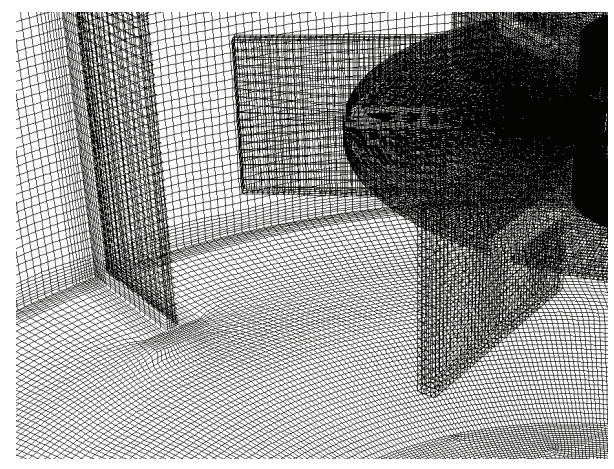

Figure 1: Mesh in the baffles vicinity and on the impeller surface in detail (LES 1).

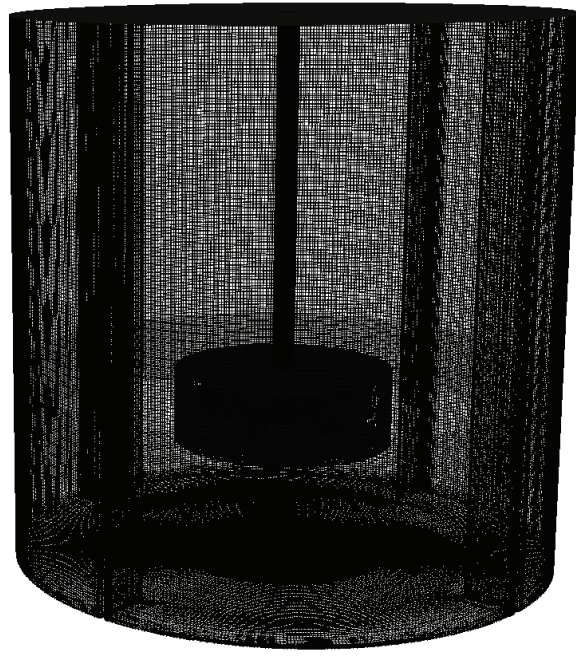

Figure 2: Mesh (LES 1) on the vessel wall and impeller with the highlighted sliding region around the impeller.

the boundary layer mesh; see Figure 1. The sliding region has cylindrical shape with distance $d / 10$ from the impeller cylindrical envelope; see Figure 2. The solved hexahedral meshes consists of 2465228 cells (LES 1) and 7435557 cells (LES 2), respectively. The larger mesh was refined, namely, in bulk vessel region to attained the maximal cell size under $2 \mathrm{~mm}$, which corresponds with maximal size of the measurement LDA volume; see Section 3. The time step must not exceed 1/60 of one revolution [11] that corresponds with $0.0032 \mathrm{~s}$ for $300 \mathrm{rpm}$. Hence, the time step $0.001 \mathrm{~s}$ was used. The calculated time was $60 \mathrm{~s}$ while the flow development required $\min 20$ revolutions $[8,13]$ which represent the first $2 \mathrm{~s}$ of the simulation. Calculated instantaneous flow field over $60 \mathrm{~s}$ in the measured plane is depicted in Figure 3.

\section{Experimental}

Measurements of the velocity profiles were carried out in a pilot plant flat bottomed mixing vessel with four baffles at its wall (see Figure 4), with water as the working liquid (density $\rho=1000 \mathrm{~kg} \mathrm{~m}^{-3}$, dynamic viscosity $\mu=1 \mathrm{mPas}$ ) under the constant impeller speed $300 \mathrm{rpm}$ (impeller Reynolds number

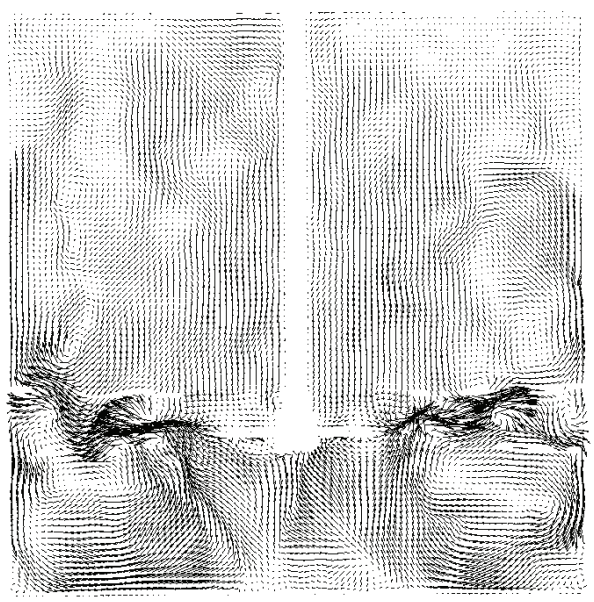

Figure 3: Calculated instantaneous flow field in measured plane between the baffles.

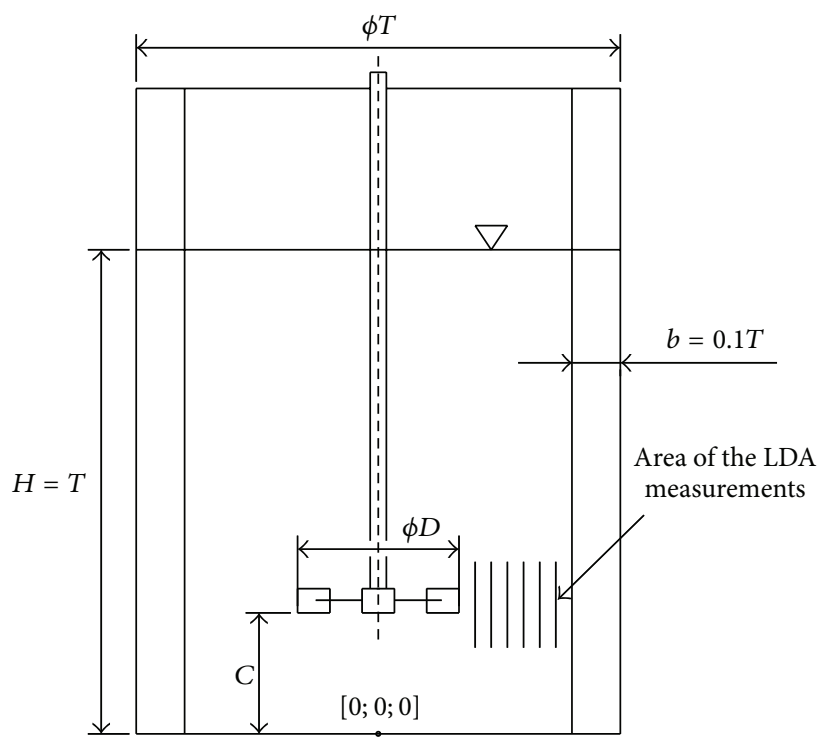

FIgURe 4: Pilot plant cylindrical vessel with a six-blade Rushton turbine $(T=300 \mathrm{~mm}, H / T=1, C / D=0.75, b / T=1 / 10$, four baffles).

$\operatorname{Re}_{M}=50$ 000). A standard Rushton impeller [22, 23] was used for the investigation (see Figure 5).

Laser Doppler Anemometry (LDA) one-component measurements of the radial velocity were performed in the impeller discharge stream (see Figure 4) in the vertical plane between two adjacent baffles in axial profiles with several distances from the impeller blade. The dimensionless radial coordinates $r^{*}=2 r / D$ were $1.2 ; 1.4 ; 1.6 ; 1.8 ; 2.0 ; 2.2$. Onecomponent LDA system setup consists of Coherent INNOVA 305 Ion-Argon laser supply with power $5 \mathrm{~W}$ and separated beam only for one component measurement on wavelength $514.5 \mathrm{~nm}$; DANTEC FiberFlow transmitting optics and P80 DANTEC BSA processor. The optic parameters were focal length $310 \mathrm{~mm}$, diameter of the beam $1.2 \mathrm{~mm}$, fringe spacing $2.67 \mu \mathrm{m}$, number of fringes 63 , and the measured volume was 


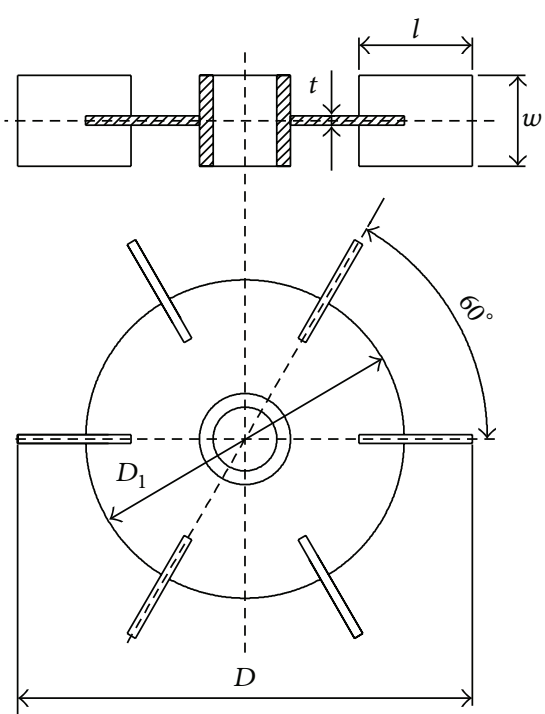

FIGURE 5: Sketch of Rushton turbine impeller, $w / D=0.2, D_{1} / D=$ 0.75 , and $l / D=0.25$.

ellipsoid with sizes of the axes $0.170 \times 0.169 \times 1.757 \mathrm{~mm}$. The used frequency shift was $40 \mathrm{MHz}$ and velocity span $7.51 \mathrm{~m} / \mathrm{s}$. The setup was supervised by BSA FLOW SOFTWARE v3.0 installed on standard PC where the data was processed. SHGS (silver coated-hollow glass Spheres) with mean diameter $10 \mu \mathrm{m}$ and density $1.1 \mathrm{~g} \cdot \mathrm{cm}^{-3}$ were used as trace particles. The measurement was performed through the glass flat bottom of the vessel to eliminate optical effects of the cylindrical walls.

\section{Results and Discussion}

Profiles of the radial mean ensemble-averaged velocity component in the dimensionless form where the radial velocity component is normalized by the impeller tip speed $V_{\text {tip }}=$ $\pi D n$ are depicted in Figures 6, 7, 8, 9, 10, and 11. The dimensionless coordinate $z^{*}$ is the distance from the impeller disk axis normalized by the half-height of the impeller blade. The profiles are depicted for six values of the dimensionless radius $r^{*}$.

The depicted results from CFD calculations and results in measured points were compared also by calculations of variance. Variance between the measured and the calculated data of dimensionless radial component of the mean ensembleaveraged velocity was calculated using the formula

$$
\operatorname{var}\left(W_{r}^{*}\right)=\frac{1}{N} \sum_{i=1}^{N}\left(W_{r \mathrm{LDA}}^{*}-W_{r \mathrm{CFD}}^{*}\right)^{2}
$$

where $N=24$ is the number of compared points on the profile $W_{r}^{*}$ with index LDA means the value obtained from LDA measurements and with index CFD is the value interpolated from calculated profile from CFD. Standard deviation $\sigma$ is expressed as the square root of the variance. The results of variance (standard deviation) in Table 1 signify that the higher discrepancy of the profiles is in the region where the zone of establishment is changing to the zone of

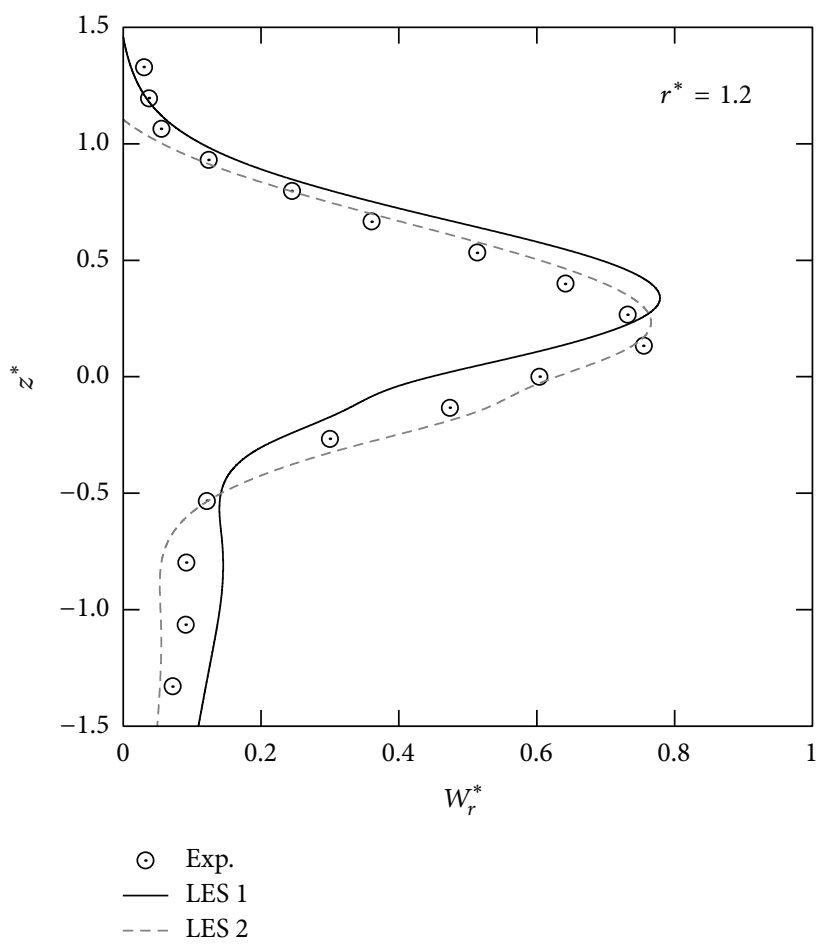

FIGURE 6: Radial component of the ensemble-averaged mean velocity at $r^{*}=1.2$.

the established flow $[1,2]$. The increase of the standard deviation with increasing dimensionless radius is probably caused by the different shape of the discharge stream and it seems to be different also at the vertical position of the stream which depends on the impeller off-bottom clearance.

The r.m.s. values of the fluctuation velocity were treated as well as the mean velocities to the dimensionless form. The two values of the dimensionless radius $r^{*}=1.4$ and 1.6 are shown in Figure 12, where the trailing vortices have an impact on the fluctuation velocity. The zone is titled the zone of establishment (ZFE) [1]. The calculated values of the fluctuations are rather lower than the measured ones. The results in the next zone titled the zone of established flow (ZEF) are depicted in Figure 13. There are compared values of the dimensionless radius $r^{*}=2.0$ and 2.2. It seems that agreement between computed and experimentally determined values of the fluctuating velocity is better in $\mathrm{ZEF}$ than in ZFE.

The power number Po was calculated from impeller torque $M_{k}$ which was obtained from the force balance on the impeller surface provided by the CFD calculations [8]:

$$
\begin{gathered}
P=2 \pi n M_{k}, \\
P o=\frac{P}{\rho n^{3} D^{5}} .
\end{gathered}
$$

For Rushton turbine, the results of the power number could be compared with the empirical correlation [22, 23], 

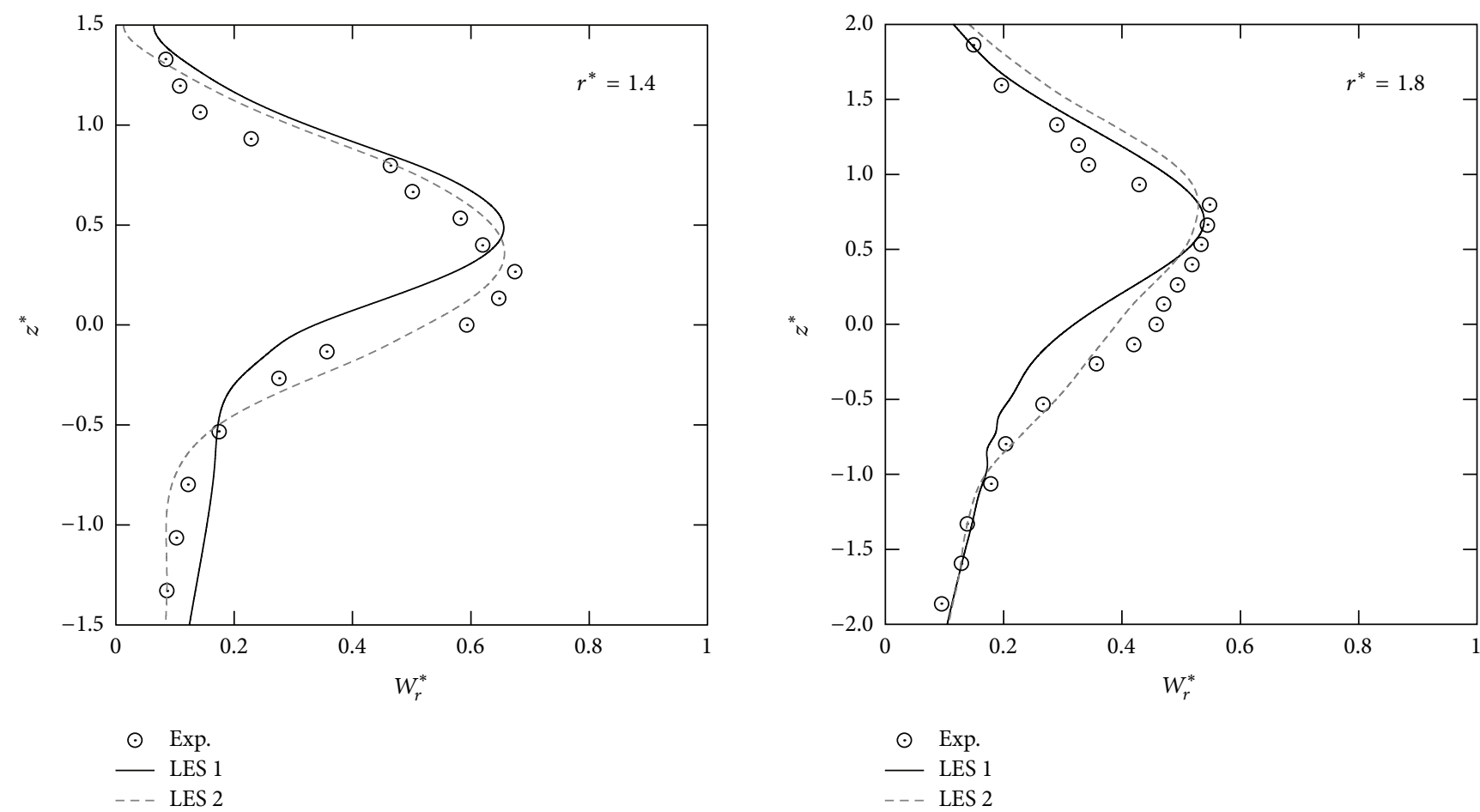

FIGURE 7: Radial component of the ensemble-averaged mean velocity at $r^{*}=1.4$.

FIgURE 9: Radial component of the ensemble-averaged mean velocity at $r^{*}=1.8$.

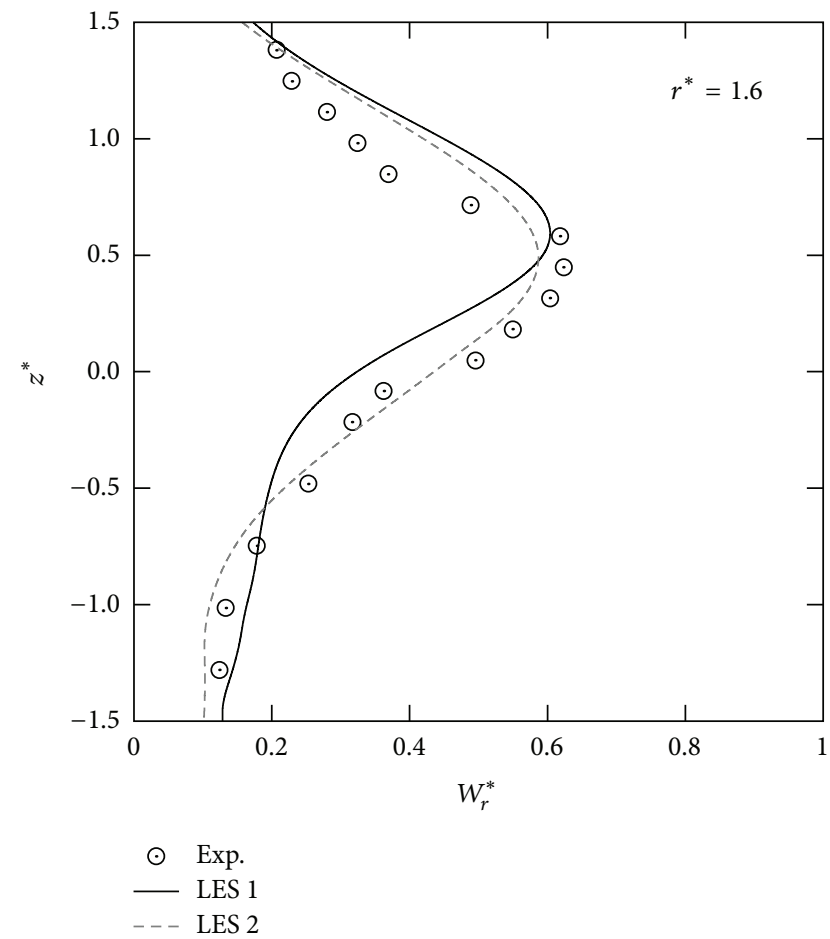

FIGURE 8: Radial component of the ensemble-averaged mean velocity at $r^{*}=1.6$.

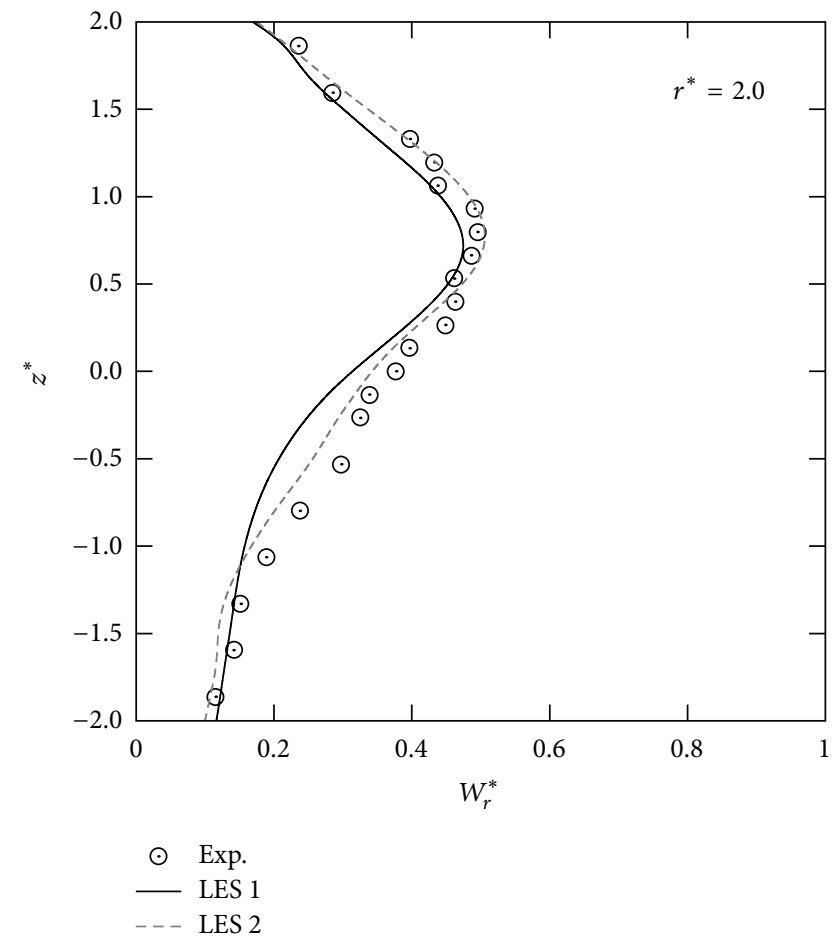

FIgURE 10: Radial component of the ensemble-averaged mean velocity at $r^{*}=2.0$. 


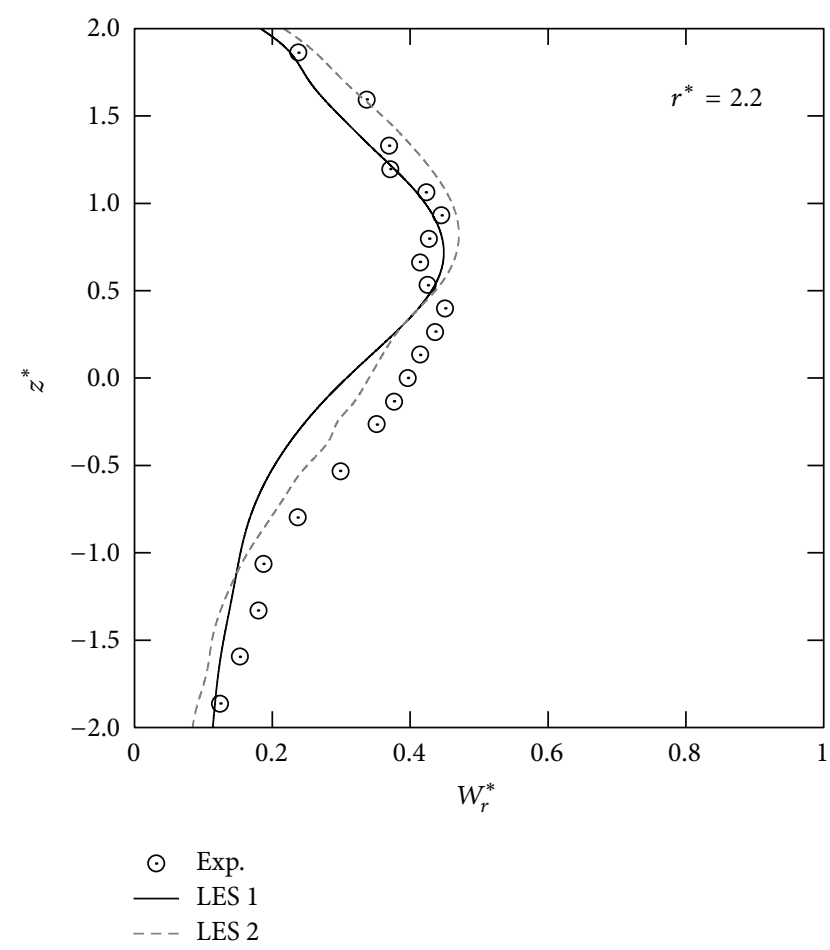

FIGURE 11: Radial component of the ensemble-averaged mean velocity at $r^{*}=2.2$.

TABLE 1: Mean variance value between LDA data of the mean ensemble-averaged radial velocity component and profiles obtained from CFD in dimensionless form.

\begin{tabular}{lcccc}
\hline & \multicolumn{2}{c}{ LES 1 } & \multicolumn{2}{c}{ LES 2 } \\
$r^{*}$ & $\operatorname{Var}\left(W_{r}^{*}\right)$ & $\sigma$ & $\operatorname{Var}\left(W_{r}^{*}\right)$ & $\sigma$ \\
\hline 1.2 & 0.0055 & 0.074 & 0.0017 & 0.042 \\
1.4 & 0.0082 & 0.090 & 0.0026 & 0.051 \\
1.6 & 0.0056 & 0.075 & 0.0024 & 0.049 \\
1.8 & 0.0042 & 0.065 & 0.0032 & 0.057 \\
2.0 & 0.0017 & 0.042 & 0.0006 & 0.024 \\
2.2 & 0.0027 & 0.052 & 0.0017 & 0.041 \\
\hline
\end{tabular}

relating the power number to the relative blade thickness $t / D$ and the relative vessel diameter $T / T_{0}$ :

$$
\text { Po }=2.512\left(\frac{t}{D}\right)^{-0.195}\left(\frac{T}{T_{0}}\right)^{0.063}
$$

where $t=2 \mathrm{~mm}$ is the thickness of the separating disc of a standard Rushton impeller and quantity $T_{0}=1 \mathrm{~m}$. The power number derived from calculations (2) was $P o=5.32$ and it is in a good agreement with power number calculated by (3), where $P o=5.00$.

\section{Conclusions}

The flow in the discharge stream from the standard Rushton turbine was calculated by the Large Eddy Simulation

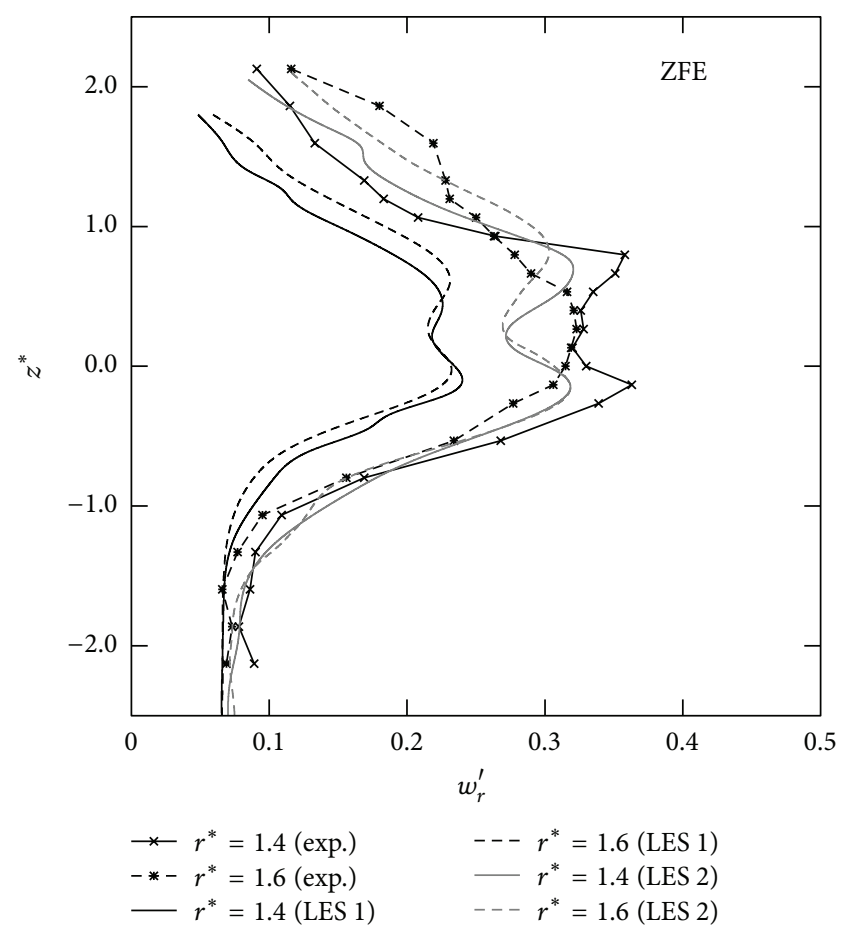

Figure 12: Comparison of axial profiles of r.m.s. values of radial fluctuation velocity in the zone of establishment (ZFE).

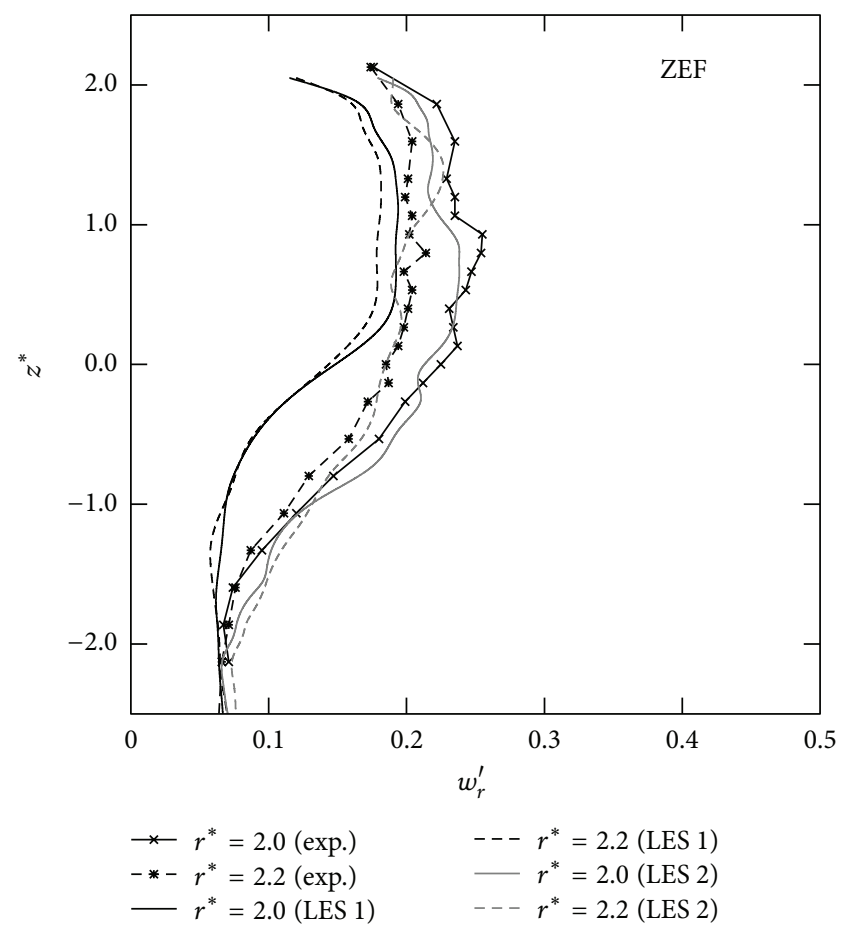

FIGURE 13: Comparison of axial profiles of r.m.s. values of radial fluctuation velocity in the zone of the established flow (ZEF).

approach. The comparison of the mean radial ensembleaveraged velocity profiles obtained from LDA measurements are in good agreement with the calculated results from both 
LES cases. The r.m.s. values of fluctuating velocity show the similar shape of profiles, but the calculations mostly underestimated the values obtained by the LDA measurements. The ensemble-averaging shows the dependency on the spatial resolution of the calculations or the measurement method; namely, the r.m.s. values of fluctuations are strongly affected by a spatial averaging. Calculated values of standard deviation from the mean velocities are increasing from lower dimensionless radius to the value $r^{*}=1.8$ where it probably indicates the boundary between the zone of the flow establishment and the zone of the established flow. The same trend is shown in the comparisons of the r.m.s. values of the fluctuating velocities. The power number $P o=5.32$ derived from the impeller torque calculations of the presented LES numerical modeling is very close to the value $P o=5.00$ estimated from empirical correlation based on experimental measurements.

\section{Nomenclature}

$\begin{array}{ll}b: & \text { Width of radial baffle }(\mathrm{m}) \\ C: & \text { Impeller off-bottom clearance }(\mathrm{m}) \\ D: & \text { Impeller diameter }(\mathrm{m}) \\ H: & \text { Height of agitated charge above vessel bottom } \\ & (\mathrm{m}) \\ h: & \text { Impeller blade width }(\mathrm{m}) \\ M_{k}: & \text { Impeller torque }(\mathrm{Nm}) \\ N: & \text { Number of experimental points } \\ n: & \text { Impeller speed }\left(\mathrm{s}^{-1}\right) \\ P o: & \text { Impeller power number } \\ r: & \text { Dimensional longitudinal (radial) coordinate } \\ & \text { (m) } \\ r^{*}: & \text { Dimensionless longitudinal (radial) coordinate } \\ \mathrm{Re}_{M}: & \text { Impeller Reynolds number Re }{ }_{M}=n D^{2} \rho / \mu \\ t: & \text { Thickness of the impeller separating disc (m) } \\ T: & \text { Mixing vessel diameter }(\mathrm{m}) \\ V_{\mathrm{tip}}: & \text { Impeller tip speed (m·s }{ }^{-1} \text { ) } \\ W_{r}^{*}: & \text { Dimensionless radial ensemble-averaged mean } \\ w_{r}^{\prime}: & \text { velocity } \\ & \text { Dimensionless root mean square value of the } \\ & \text { radial component of fluctuating velocity. }\end{array}$

Greek Symbols

$\mu$ : Dynamic viscosity (Pa s)

$\rho$ : Density $\left(\mathrm{kg} \mathrm{m}^{-3}\right)$

$\sigma$ : Standard deviation.

\section{Conflict of Interests}

The authors declare that they have no conflict of interests regarding the publication of this paper.

\section{Acknowledgments}

This research has been subsidized by the Research Project no. GA CR P101/12/2274 and RVO: 67985874.

\section{References}

[1] R. Ben-Nun and M. Sheintuch, "Characterizing turbulent jet properties of radial discharge impeler: the zone of flow establishment (ZFE) and ZEF," AIChE Journal, 2013.

[2] R. Ben-Nun and M. Sheintuch, "Charcterizing turbulent jet properties of radial discharge impeller: potential core, spreading rate and averaged flow field parameters," in Proceedings of the 9th European Congress of Chemical Engineering, The Hague, The Netherlands, April 2013.

[3] S. Yeoh, G. Papadakis, and M. Yianneskis, "Numerical simulation of turbulent flow characteristics in a stirred vessel using the LES and RANS approaches with the sliding/deforming mesh methodology," Chemical Engineering Research and Design, vol. 82, no. 7, pp. 834-848, 2004.

[4] J. B. Joshi, N. K. Nere, C. V. Rane et al., "CFD simulation of stirred tanks: comparison of turbulence models. Part I: radial flow impellers," Canadian Journal of Chemical Engineering, vol. 89, no. 1, pp. 23-82, 2011.

[5] J. B. Joshi, N. K. Nere, C. V. Rane et al., "CFD simulation of stirred tanks: comparison of turbulence models (Part II: axial flow impellers, multiple impellers and multiphase dispersions)," Canadian Journal of Chemical Engineering, vol. 89, no. 4, pp. 754-816, 2011.

[6] M. Coroneo, G. Montante, A. Paglianti, and F. Magelli, "CFD prediction of fluid flow and mixing in stirred tanks: numerical issues about the RANS simulations," Computers and Chemical Engineering, vol. 35, no. 10, pp. 1959-1968, 2011.

[7] A. Barker, R. D. Laroche, M. H. Wang, and R. V. Calabrese, "Sliding mesh simulation of laminar flow in stirred reactors," Chemical Engineering Research and Design, vol. 75, no. 1, pp. 4244, 1997.

[8] J. Gimbun, C. D. Rielly, Z. K. Nagy, and J. J. Derksen, "Detached eddy simulation on the turbulent flow in a stirred tank," AIChE Journal, vol. 58, no. 10, pp. 3224-3241, 2012.

[9] J. Derksen and H. E. A. Van Den Akker, "Large eddy simulations on the flow driven by a Rushton turbine," AIChE Journal, vol. 45, no. 2, pp. 209-221, 1999.

[10] J. Derksen, "Long-time solids suspension simulations by means of a large-eddy approach," Chemical Engineering Research and Design, vol. 84, no. 1, pp. 38-46, 2006.

[11] A. Bakker and L. M. Oshinowo, "Modelling of turbulence in stirred vessels using large eddy simulation," Chemical Engineering Research and Design, vol. 82, no. 9, pp. 1169-1178, 2004.

[12] M. Jahoda, M. Moštěk, A. Kukuková, and V. Machoň, “CFD modelling of liquid homogenization in stirred tanks with one and two impellers using large eddy simulation," Chemical Engineering Research and Design, vol. 85, no. 5, pp. 616-625, 2007.

[13] Z. Li, M. Hu, Y. Bao, and Z. Gao, "Particle image velocimetry experiments and large eddy simulations of merging flow characteristics in dual Rushton turbine stirred tanks," Industrial and Engineering Chemistry Research, vol. 51, no. 5, pp. 2438-2450, 2012.

[14] Z. Li, Y. Bao, and Z. Gao, "PIV experiments and large eddy simulations of single-loop flow fields in Rushton turbine stirred tanks," Chemical Engineering Science, vol. 66, no. 6, pp. 12191231, 2011.

[15] J. J. Gillissen and H. E. Van den Akker, "Direct numerical simulation of the turbulent flow in a baffled tank driven by a Rushton turbine," AIChE Journal, vol. 58, no. 12, pp. 3878-3890, 2012. 
[16] V. Koláŕ, P. Filip, and A. Curev, "Hydrodynamics of radially discharging impeller stream in agitated vessels," Chemical Engineering Communications, vol. 27, no. 5-6, pp. 313-326, 1984.

[17] J. Drbohlav, I. Fořt, K. Máca, and J. Ptáček, “Turbulent characteristics of discharge flow from turbine impeller," Collection of Czechoslovak Chemical Communications, vol. 43, no. 12, pp. 3148-3161, 1978.

[18] I. Fořt, H. O. Möckel, J. Drbohlav, and M. Hrach, "The flow of a liquid in a stream from the standard turbine impeller," Collection of Czechoslovak Chemical Communications, vol. 44, no. 3, pp. 700-710, 1979.

[19] A. Obeid, I. Fořt, and J. Bertrand, "Hydrodynamic characteristics of flow in systems with turbine impeller," Collection of Czechoslovak Chemical Communications, vol. 48, no. 2, pp. 568577, 1983.

[20] J. Talaga and I. Fořt, "The velocity field in the discharge stream from a rushton turbine impeller," in Proceedings of the 14th European Conference on Mixing, Warszava, Poland, September 2012.

[21] B. C. Venneker, J. J. Derksen, and H. E. A. Van den Akker, "Turbulent flow of shear-thinning liquids in stirred tanksThe effects of Reynolds number and flow index," Chemical Engineering Research and Design, vol. 88, no. 7, pp. 827-843, 2010.

[22] W. Bujalski, A. W. Nienow, S. Chatwin, and M. Cooke, "The dependency on scale of power numbers of Rushton disc turbines," Chemical Engineering Science, vol. 42, no. 2, pp. 317326, 1987.

[23] K. R. Beshay, J. Kratěna, I. Fořt, and O. Brůha, "Power input of high-speed rotary impellers," Acta Polytechnica, vol. 41, no. 6, pp. 18-23, 2001. 

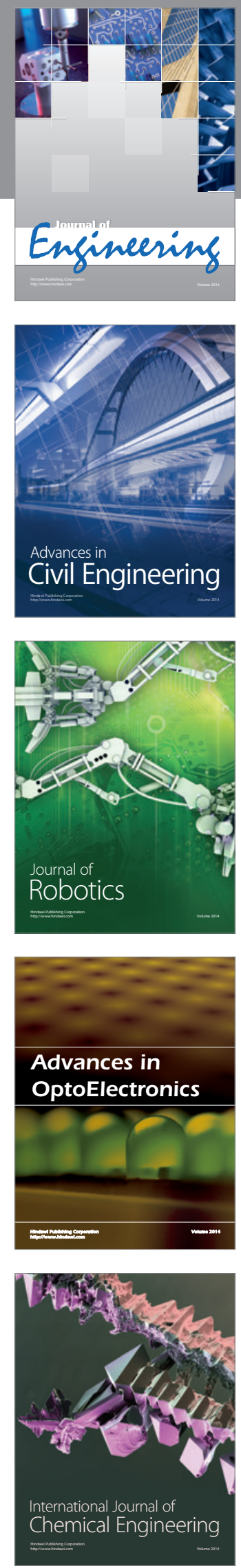

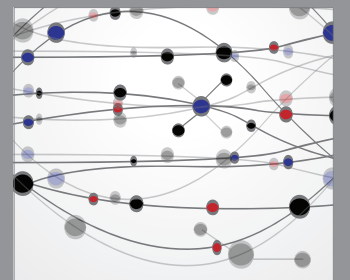

The Scientific World Journal
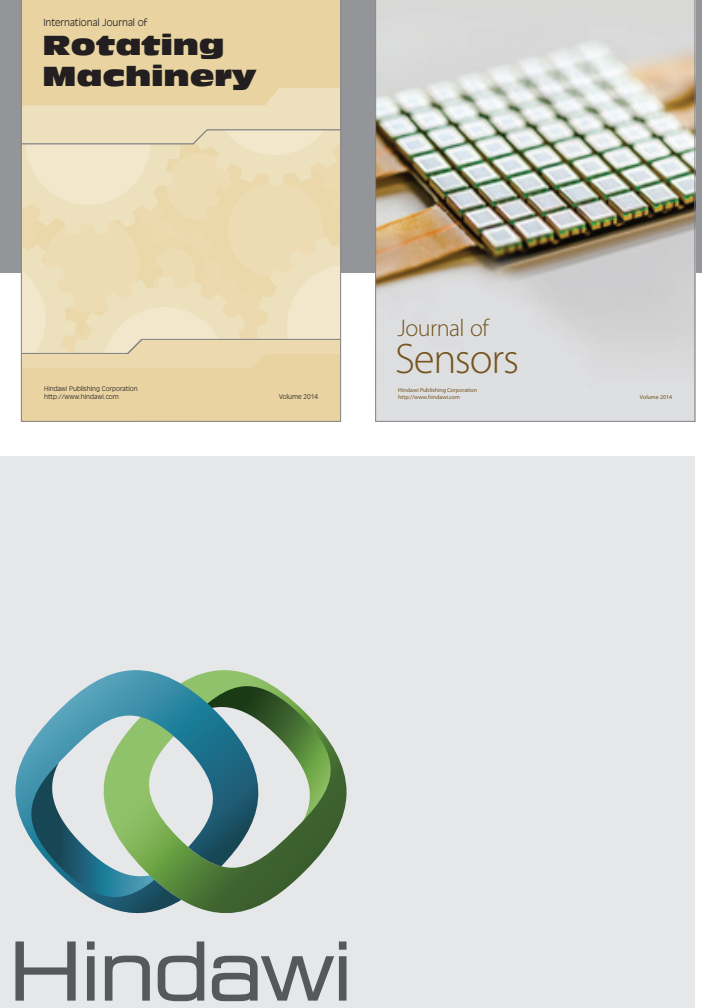

Submit your manuscripts at http://www.hindawi.com
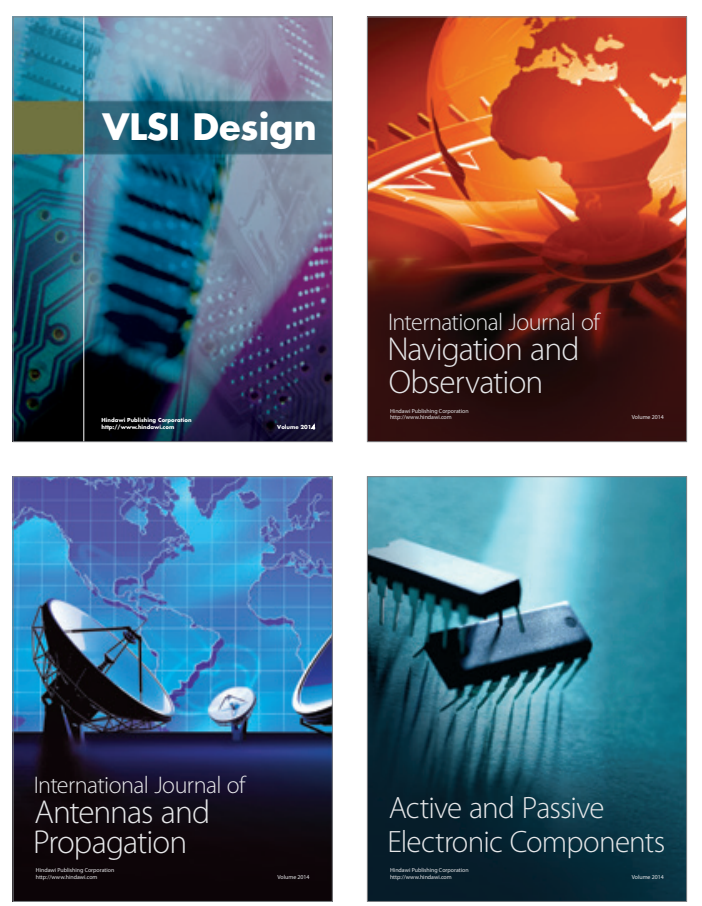
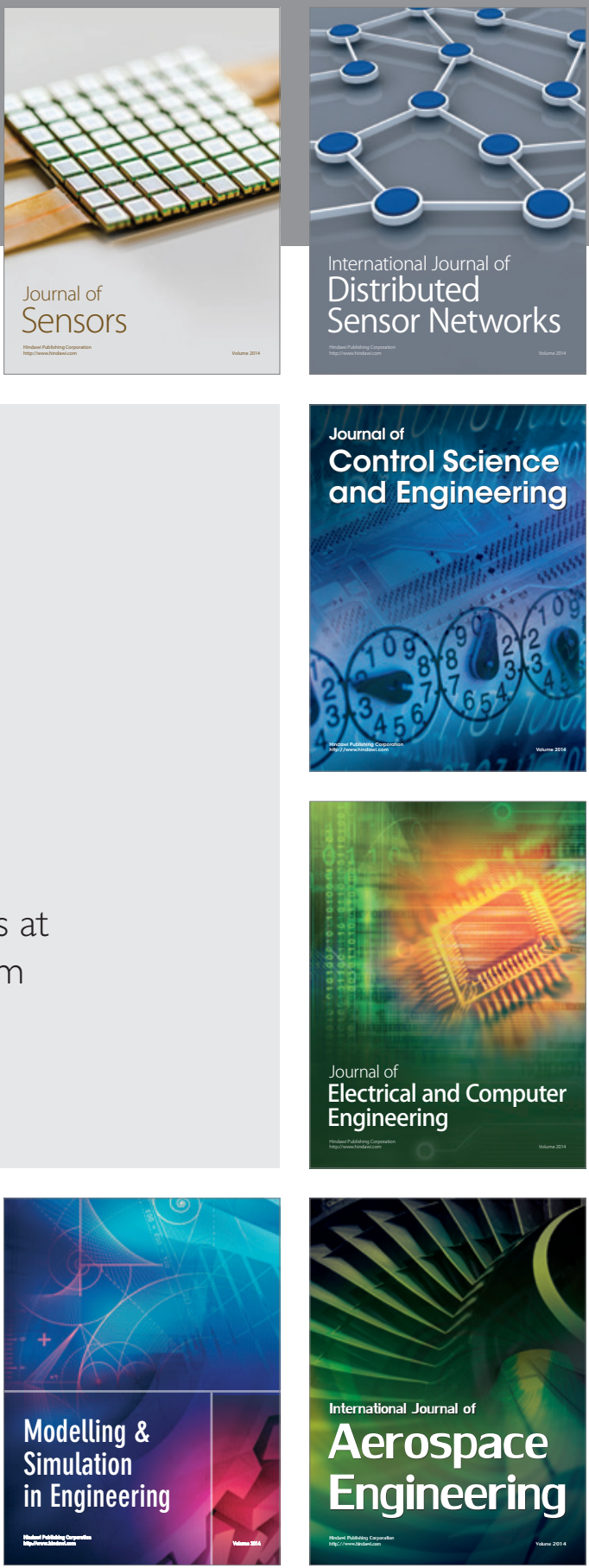

Journal of

Control Science

and Engineering
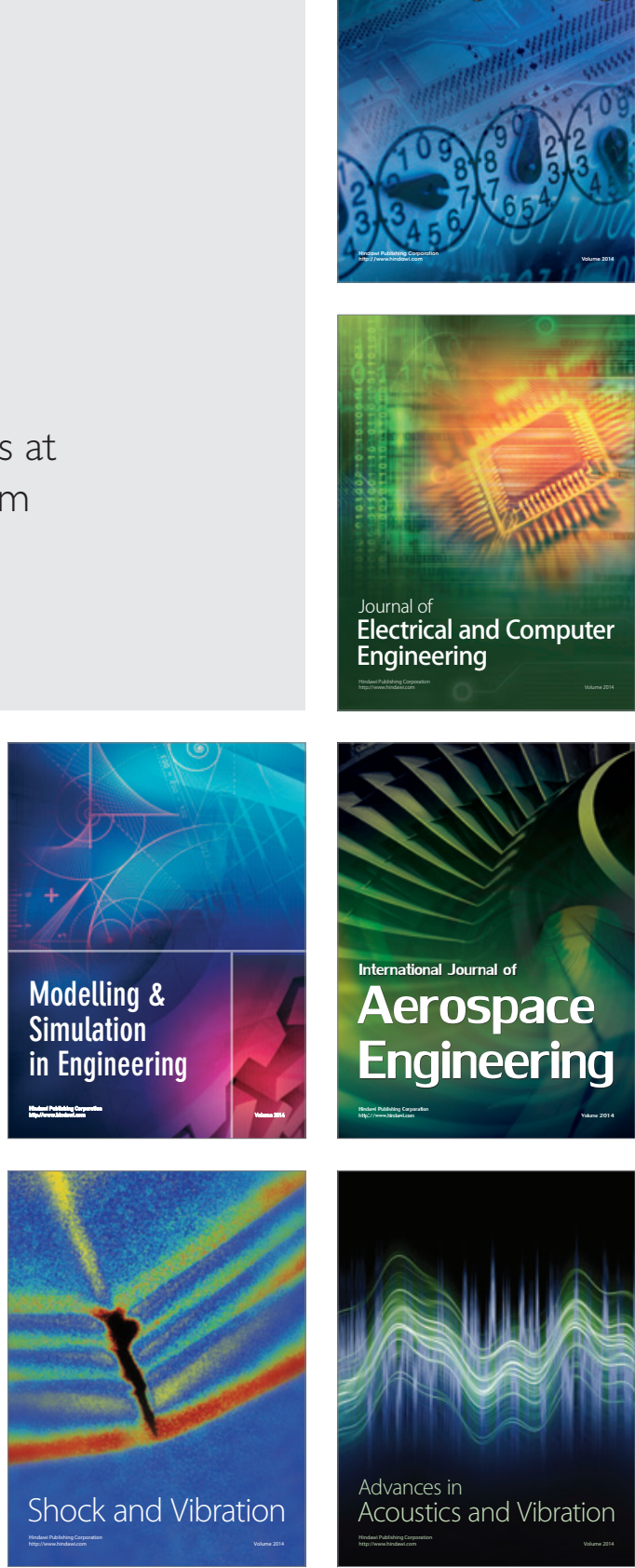